NBER WORKING PAPER SERIES

PRICING FHA MORTGAGE DEFAULT INSURANCE

Donald F. Cunningham

Patric F. Hendershott

Working Paper No. 1382

\author{
NATIONAL BUREAU OF ECONOMIC RESEARCH \\ 1050 Massachusetts Avenue \\ Cambridge, MA 02138 \\ June 1984
}

This research has been supported by the U.S. Department of Housing and Urban Development (HC-5488, Task Order \#5). The research reported here is part of the NBER's research program in Financial Markets and Monetary Economics. Any opinions expressed are those of the authors and not those of the National Bureau of Economic Research. 
The fair premia on FHA mortgage default insurance contracts are computed under alternative assumptions regarding the expected house price inflation rate and its variance and homeowner's default costs. The contracts considered vary by amortization schedule (15 and 30 year level-payment mortgages and two graduated-payment mortgages) and initial loan-to-value ratio (80 to 95.8 percent). The results indicate a wide variation in fair insurance premia. Because FHA charges all borrowers the same premia, large cross-subsidies exist within the program, with borrower's obtaining low loan-to-value or rapidly amortizing loans subsidizing borrowers with high loan-to-value or negative amortizing loans. Moreover, the movement toward insuring riskier loans -graduated payment, price-level adjusted and adjustable rate -- without increasing insurance premia seems almost certain to lead to significant overall losses for the program.

Donald F. Cunningham Federal Home Loan Mortgage Corporation 1776 G ST. N.W.

P.O. Box 37248 Washington, D.C. 20013 (202) 789-5013
Patric H. Hendershott 321 Hagerty Hall 1775 College Road Ohio State University Columbus, OH 43210 (614) 422-0552 


\section{Pricing FHA Mortgage Default Insurance}

Donald F. Cunningham and Patric H. Hendershott

In late 1976, FHA introduced the graduated-payment mortgage (GPM) under Section 245 (a) of the National Housing Act. In an effort to offer this program to potential homebuyers who would not otherwise qualify, authority was extended in 1980 to loans with lower down payments under section 245 (b) of the act. In early 1983, FHA began insuring 15-year level-payment mortgages. Obviously these three mortgages amortize at different rates than each other and than the standard 30-year level payment mortgage and thus likely have different default risk. Nonetheless, the FHA fee for default insurance on these new instruments has been the same half percentage point charged on the standard 30-year mortgage. ${ }^{1}$

This study compares default risk on the FHA 245 (b) GPM loan program and the new 15-year level-payment mortgage with the standard 30-year level-payment mortgage. The study provides measures of the appropriate FHA default insurance premia in a competitive market under various assumptions regarding the expected house price inflation rate and its variance. Our methodology is an application of the Black and Scholes (1973) option pricing model as modified by Brennan and Schwartz (1977). In this procedure the insurance premium is conceptualized as a put option sold by FHA and purchased by the homebuyer for the default protection of the lender. ${ }^{2}$ Unlike private mortgage

\footnotetext{
l Legislation passed in late 1983 allows FHA to insure PLAMs, SAMs and ARMs. Alternatives to the half point fee structure are also available, but none of the possible structures differentiates between mortgage instruments. See Pesando and Turnbull (1983) for a simulation analysis suggesting that all non-level payment mortgages, except the SAM, are subject to greater default risk than the level payment mortgage.

2 For an instructive discussion of the pricing of default insurance, including both references to the iiterature on the determinants of foreclosure and thoughtful comments on the use of option models, see Swan (1982).
} 
insurance, there is no residual default risk retained by the lender.

This paper is divided into four sections. The first discusses household default behavior, and the second describes the model for pricing default insurance and procedures for obtaining price estimates. The third presents and interprets the estimates and draws some implications for yields on alternative fixed-rate conventional mortgages. A summary concludes the paper.

I. The Household Default Decision ${ }^{3}$

This section states the condition for borrower default and discusses default or moving costs.

\section{The Critical House Price and Default}

A household will default if its house price falls sufficiently that the gains from default exceed the costs. The gains are the recapture of the negative equity $\left(M_{t}-H_{t}\right)$ and the free rent earned between default and foreclosure, $R_{t}$. We assume this foreclosure period is one year. The costs of default for the ith household are $c_{t}^{i}$. Thus default will occur in period $t+l$ if

$$
M_{t}-H_{t}+R_{t}>C_{t}^{i}
$$

We assume that the costs of default are a fraction, $\phi$, of the house value (see below) and that the free rent at the time of default is 10 percent of the value of the house at that time. Then

\footnotetext{
For recent explanations of actual default behavior, see Campbell and Dietrich (1983) and Foster and Van order (1984).
} 


$$
M_{t}-H_{t}+0.1 H_{t}>\phi H_{t}
$$

and the critical house price below which the ith household will default is

$$
\overline{\mathrm{H}}_{t}=\frac{1}{0.9+\phi{ }^{\mathrm{M}}} \cdot
$$

All new mortgages are assumed to be priced two points below par. The outstanding mortgage balance over time is easily computed from the initial house price and loan-to-value ratio and standard outstanding balance formulae.

The uncertain variable is the house price. Changes in house prices are assumed to be normally distributed with mean $q$ and standard deviation $\sigma$. The level of house prices is then lognormally distributed with mean in period $t$ of $\mathrm{H}_{\mathrm{O}} \mathrm{e}^{t \mu}$, where $\mathrm{H}_{\mathrm{O}}$ is the initial house price and $\mu=\mathrm{q}+\sigma^{2} / 2.4$ The lognormal probability density function is

$$
f_{t}(H)=\frac{1}{H \sigma \sqrt{2 \pi t}} \exp -\left[\frac{1}{2} \frac{[\ln H-t q]}{t \sigma^{2}}\right] .
$$

The fraction of households that will have defaulted by time $t$ is the integral of the lognormal probability density function from 0 to $\overline{\mathrm{H}}_{t} / \mathrm{H}_{\mathrm{O}}$,

$$
F\left(\overline{\mathrm{H}}_{t} / \mathrm{H}_{0}\right)=\int_{0}^{\overline{\mathrm{H}}_{t} / \mathrm{H}_{0}} f_{t}(\mathrm{H}) d \mathrm{H},
$$

$\overline{4}$ The variance of house prices is $e^{2 t \mu}\left(e^{t \sigma^{2}}-1\right)$. 
plus the fraction of households that defaulted in earlier periods (had $\mathrm{H}_{t-i}<$ $\overline{\mathrm{H}}_{t-i}$ ' but would now have house prices greater than $\overline{\mathrm{H}}_{t}$.

\section{$\underline{\text { Household Costs of Default }}$}

The costs of default vary widely across households depending on the best housing alternatives available to them, the laws of the jurisdiction in which they reside, and their "psychological aversion" to default. Say that the psychic costs are zero, the jurisdiction does not allow recourse to other assets the household has, and the optimal housing choice is renting a unit in the same geographical area. The costs are then only those of locating the rental unit and moving the family belongings. At most, these costs might be 5 percent of the house sold.

Costs will be greater if the optimal housing choice is purchasing another house. Say that due to the default the houseinold will be unable to obtain mortgage credit for ten years. The costs of default increase by the present value of the advantage of owning over renting for the next ten years. Even if a mortgage can be obtained, costs are greater than in the rentaloptimum case. First, the house must be purchased and thus brokerage fees must be paid. On the assumption that the house purchased is the same value as that sold, these costs might be 7 percent of the house sold. Second, the household must pay for insurance on a new mortgage, if one is obtained, and must put some equity down, equity that is at risk. Because the former house had less value than the outstanding mortgage, the household had complete protection against house price declines; that protection does not exist on repurchases after default. 
The costs of default, when owning another house is the best housing alternative, can be modeled conceptually. If owning would provide an aftertax advantage of $a^{i} H_{t+j}$ for each year the ith household is forced to forego ownership and there are $m$ such years, then this component of default costs is

$$
\sum_{j=1}^{m} a^{i} H_{t+j} e^{-r j}=H_{t} a^{i} \Sigma e^{-(r-\mu) j}=\left(A D V^{i}\right) H_{t}
$$

where $r$ is the borrower's after-tax discount rate. ${ }^{5}$ If, on the other hand, the purchase of another house is viable, an estimate of the cost of accepting downside house-price risk is needed. Assume that the household equity finances the house and expects to hold it for $n$ years. The cost of downside risk is the present value of the difference in the expected house price in period $t+n$ where the house price distribution is truncated at $\mathrm{H}_{t}$ (guaranteeing against price decline) and the expected price without truncation. This value is

$$
\left[H_{t} \int_{0}^{H_{t}} f_{n}(H) d H-\int_{0}^{H_{t}} H_{n}(H) d H\right] e^{-r n}=(P R O) H_{t} .
$$

\footnotetext{
5 The ADV term is also affected by the tax consequences of default (as C.F. Sirmans reminded us). If the potential defaulter is a first-time buyer, then he would receive $\tau g\left(H_{-}-M_{H}\right)$ from the Treasury upon default, where $\tau g$ is the homeowner's capital gains Eax rate. That is, tax consequences mitigate the cost of foregoing homeownership. On the other hand, if the potential defaulter had earned a substantial deferred capital gain on an earlier house purchase, a tax payment could be due.
} 
This might appear to be an underestimate of the cost if some risky debt finance is employed because lenders/insurers will have to charge a greater fee than the cost of the house value declining below the mortgage owing to both the lost interest and maintenance during the foreclosure period and the costs of selling the house. However, households gain the possibility of receiving rent-free housing for a year in return for the higher cost.

Finally, households with attachable assets and/or psychological aversion to default will have higher costs than other households regardless of the optimal housing choice.

All of the factors can be combined into a general expression for default costs for the ith household in period $t$ as

$$
\text { where } \alpha_{t}^{i}= \begin{cases}C_{t}^{i}=\left(.05+\alpha_{t}^{i}+B_{t}^{i}\right) H_{t} \\ A D V_{t} & \text { renters by choice } \\ .07+\text { PRO } & \text { forced to rent }\end{cases}
$$

and $\beta_{t}^{i}$ reflects the costs owing to attachable assets and/or noneconomic aversion to default.

Given that the household originally chose to own, it will still wish to own in the absence of changes in the relative costs of owning and renting. Thus in our ex ante analysis with the only uncertainty being house prices, there are not households who would be renters by choice after default.

For purposes of evaluating the default costs of households who would be forced to rent or would continue to own, we assume $q=0.05, \sigma^{2}=0.01$ (and thus $\mu=0.055$ ) and $x=0.11$. Assuming a forced tenancy period of 6 to 10 
years [evaluating $(2 a)$ for $m=6$ and 10 and $a^{i}=0.01$ ], those forced to rent give up 0.05 to 0.075 of the house price for each percentage point advantage owning gives over renting. For households using FHA financing in a period of high real interest rates, a one to two percentage point advantage seems reasonable. For the higher tax-bracket households that utilize conventional financing, the advantage could be greater. Adding the 0.05 basic default cost and letting $\beta$ range from 0.05 to 0.10 , the cost of default for these households would range from roughly 15 to 30 percent of the value of the house. ${ }^{6}$ The cost of downside risk (PRO) for households that can continue ownership is only 1 to 2 percent of the value of the house, looking 4 to 8 periods into the future [evaluating (7b) for $\mathrm{n}=4$ and 8 ]. Allowing for risk aversion and possible difficulties in coming up with the new downpayment might make the effective cost 3 percent. The sum of the basic default cost of 0.05 , the 0.07 broker's fee, the 0.03 and a $\beta$ ranging from 0.05 to 0.10 gives a cost of default for these households of 20 to 25 percent of the value of the house. We rewrite (4) as

$$
c_{t}^{i}=\varnothing H_{t}^{\prime}
$$

where $\varnothing$ ranges from 0.15 to 0.30 .

\footnotetext{
In a period of lower real (after-tax) interest rates, default costs (the ADV ${ }^{i}$ term) would be greater for two reasons. First, an increase $q$ (and thus $\mu$ ) or a decrease in $r$ lowers the real discount rate and thus raises the ${ }_{i}$ present value of the advantages of homeownership foregone for any given ${ }^{i}$ (the annual advantage to homeownership). To illustrate, a $q$ of 0.08 or $r$ of 0.075 raises the cost for $a^{1}=0.01$ from the 0.05 to 0.075 range to roughly 0.055 to 0.088 . second, with a lower real after-tax rate, the annual advantage of homeownership will be greater. The upper end of range of default costs could well rise to 45 percent.
} 
In the above evaluation of default costs $(\phi)$, households have been assumed to have the option of remaining in their houses in the absence of default. If households should have to move, then the moving costs attributable to default are reduced. Most obviously, the $0.05 \mathrm{H}_{t}$ costs of locating a rental unit and moving the family belongings do not deter default. In addition, many of these households will be "forced" to rent temporarily until their finances are again in order. Thus, only part of the ADV loss is attributable to default. Finally, the costs of selling their existing houses adds an incentive to default because these costs are avoided by default. With these costs equal to $0.07 \mathrm{H}_{t}$ and the reduction in ADV attributable to default equal to $0.03 \mathrm{H}_{t}$, default costs for those who have to move are reduced by $0.15 \mathrm{H}_{t^{*}}$ Thus $\varnothing$ would range between 0 and 0.15 for such households. 7

II. The Simulation Model and Procedures FHA or mortgage insurers/lenders can charge for expected default losses in a one-time up front fee, a higher mortgage coupon rate, or some combination of the two. From the above analysis, expected losses on any mortgage contract depend on both the likelihood of default and the expected loss associated with it, i.e., on the "known" mortgage path and the probabilities of alternative house price paths, as well as household default costs. Let the fair price for a mortgage insurance contract be denoted by $I_{t}$. Initially, $I_{0}$ is the price of a contract that would be offered to borrowers under specific assumptions regarding the mean and variance of house price inflation, the interest rate,

\footnotetext{
7 Default risk on ARMs is thus higher than on FRMs because a jump in interest rates might force households with ARMs to move. For another reason, also related to the differential impact of increases in interest rates, why default risk is greater on ARMs, see note 12 .
} 
the initial loan-to-value ratio, the mortgage amortization schedule and household default costs. Over time, $I_{t}$ reflects the price an insurer would have to pay another insurer to take over the default contract.

In competitive markets, insurance contracts can only be sold for a fair premium. That is, arbitrage profits could not be earned by simultaneously taking an equivalent position (either long or short) in the house against which the insurance is written. In what follows, we hypothesize that FHA desires to charge this fair premium. Our task, then, is to derive a pricing equation for I that is consistent with zero arbitrage profits. The technique is to have a household form a riskless hedge consisting of the purchase of a partially debt-financed house and the appropriate number of insurance contracts on the mortgage. The investment in this hedge -- the downpayment on the house plus the outlay for mortgage insurance contracts -- must then earn the riskless rate of return $(r)$.

Borrowing from the logic of Black and Scholes, the hedged position consists of the purchase of a house and $1 / I_{H}$ insurance contracts, where the subscript denotes a partial derivative. $I_{H}$ is negative -- the amount one would have to pay another insurer to assume the contract rises as the house value falls -- and is more negative the greater is the loan-to-value ratio. Thus fewer contracts are purchased if a lower downpayment is made. The hedge requires an equity investment of $\mathrm{H}-\mathrm{M}-\mathrm{I} / \mathrm{I}_{\mathrm{H}}$, where $\mathrm{M}$ is the book value of the mortgage.

We assume the hedge could be continuously adjusted according to the changes in the ratio $1 / I_{H^{\prime}}$ making it a perfect hedge. In the absence of taxes, the return on the housing purchase consists of the change in the house 
price $(\mathrm{dH})$ plus net operating income (denoted by $\mathrm{sH}$ ). The cost of the fully insured mortgage is simply the risk-free rate under the assumption of constant interest rates, and the return on the insurance is just dI. Thus we can write the total return to the equity position as

$$
d H+s H d t-r M d t-d I / I_{H}=\left(H-M-I / I_{H}\right) r d t .
$$

Note that the terms in $M$ cancel.

The risk of investing in the house (or in insuring it) is assumed to lie solely in uncertainty regarding future house prices. Changes in the price of the house are assumed to follow the diffusion process:

$$
\frac{\mathrm{dH}}{\mathrm{H}}=q \mathrm{dt}+\sigma \mathrm{dz}
$$

where $q$ is the drift term, $d z$ is a weiner process, and $\sigma^{2}$ is the instantaneous variance of the house price. If $I$ is a smooth function of $H$, it then follows from Ito's lemma that $I$ is also an Ito process and can be expanded in the following form:

$$
d I=I_{H} d H+I_{t} d t+\frac{1}{2} I_{H H} \sigma^{2} H^{2} d t
$$

Substituting (6) into (4), simplifying and replacing $r-s$ with $q$ results in:

$$
I_{t}=r I-q H I_{H}-\frac{1}{2} \sigma^{2} H^{2} I_{H H^{\prime}}
$$

the partial differential equation governing equilibrium insurance premia in a world without taxes. It is shown in the appendix that $q=r-s$ in a taxless 
world and that (4') also holds in a world with taxes. We confirm that the hedge is perfect because the stochastic term $\left(I_{H} d H\right)$ in (6) is successfully eliminated, leaving the insurance premium a function of only observable parameters.

We utilize the Brennan and Schwartz (1977) finite difference procedure to approximate a solution to equation (4'). For each partial derivative, we substitute a central difference approximation, and the algorithm is taken over discrete increments in the house price for months between the present and the date the insurance contract expires. The key boundary condition for the solution is that if the house price hits the critical value $\bar{H}_{t}$ defined in (l) the household defaults and the insurance contract takes on the value of the insurer's loss. ${ }^{8}$ This loss is the mortgage balance plus accrued interest during the foreclosure period less the house value at the time of default (adjusted for the absence of maintenance during this period and for selling costs). We take the loss, and thus the value of I upon default $(\hat{I})$, in period $t$ to be

$$
\hat{I}_{t}=\left(1.15 M_{t}-.85 \bar{H}_{t}\right) e^{-r}=[1.15-.85 /(.9+\phi)] M_{t} e^{-r} .
$$

The loss is discounted by one period owing to the assumed one year foreclosure lag.

8 Other obvious boundary conditions are that $I_{t}$ is nonnegative and equals zero as $\mathrm{H}_{t}$ approaches infinity. 


\section{Price Estimates}

Three sets of price estimates are reported below. All provide one-time prices as a percent of the initial mortgage balance and (approximate) annual equivalent fees as a percent of the outstanding mortgage balance. Estimates are provided for four types of mortgages (15 and 30 year level payment and the two 245b GPM programs) and four loan-to-value ratios $(80,88,92$ and 95.8 percent). The highest of these ratios is based upon the minimum downpayment a household could make on a $\$ 60,000$ house in early 1983.9

Section A provides results for the basic parameterization. This includes an expected inflation rate (q) of 0.05 and a house price variance $\left(\sigma^{2}\right)$ of $0.01 .^{10}$ The mortgage rate is taken to be 13 percent, and the riskfree rate to be $11 \frac{1}{2}$ percent. This difference reflects the existence of prepayment risk. $^{11}$ The sensitivity of the insurance prices to alternative parameter values is considered in section $B$, and an extension to the conventional mortgage market is given in section $\mathrm{C}$.

Before getting to the actual estimates, a few caveats are in order. Because we have not modeled interest rate uncertainty, the one-time estimates of fair default fees are on the high side. If interest rates should rise significantly, the market value of the mortgage debt declines and households,

\footnotetext{
9 At that time the minimum downpayment on the first $\$ 25,000$ of house financed by FHA was 3 percent; on larger amounts the minimum was 5 percent. Thus the maximum loan on a $\$ 60,000$ house was $.97(\$ 25,000)+.95(\$ 60,000-25,000)$. Under new legislation the required 5 percent downpayment will not go into effect until $\$ 50,000$.

10 Asay (1978) estimated a house price variance rate of 0.0142 for the period 1966 to 1977 in southern California. Recently, Foster and Van order (1984) found a house price variance of 0.0081 to provide the best fit for their default model using FHA data from the 1960s and 1970s.

${ }^{11}$ Buser and Hendershott (1984) show that the price of this risk, when charged for in the mortgage coupon rate, is virtually identical for the four different mortgage instruments covered.
} 
being reluctant to give up what would then be below-market financing, are less likely to default. ${ }^{12}$ This gain in reduced default probability is not fully offset by the cost of increased default probability if interest rates should decline because, if the decline is sufficient, households will avoid the higher market value debt by refinancing. There is an offsetting factor at work in the calculation of the annualized default fees, however. The fees are computed assuming payment over a full 12 year period. Should the loan be terminated (called or defaulted upon) prior to the twelve year, then the fees earned are insufficient to cover the present value of expected losses. Thus there is not reason to believe that the annualized fees are necessarily too high.

\section{A. The Basic Results}

Table 1 contains the prices for three different values of the default cost parameter, $\phi$. Of course, the fees, both one-time and annualized, are higher the greater the loan-to-value ratio, the less rapidly the mortgage amortizes, and the lower the default costs. In general, raising the default costs from 0.15 to 0.225 cuts the fair insurance fee by 65 percent for the 15-year mortgage, 50 percent for the 30-year level-payment mortgage and 40 percent for the graduated-payment mortgages. For the specific parameter values assumed, FHA's half point fee on the 30-year level-payment mortgage seems to be roughly correct for a 95 percent loan-to-value ratio.

12 For this reason, default risk on FRMs is less than that on ARMs (the amount less being greater the shorter the adjustment period and the less restrictive the caps on the ARM). See note 7 for another reason related to differential impacts of interest rate increases. 
To facilitate an understanding of how insurance premia ought to vary across loan-to-value ratios, the data in Table 1 have been standardized around the 92 percent ratio in Table 2. That is, all one-time fees for each type mortgage have been divided by the fee for the 92 percent loan. These data are consistent with von Furstenburg's early (1970) discussion of cross-subsidies within the 30-year level-payment FHA program. More specifically, if the 50 basis point fee were correct for a 92 percent loan-to-value ratio, then only 30 basis points should be charged on a 88 percent loan and 10 basis points on an 80 percent loan. In contrast, at least 80 basis points should be charged on a 95.8 percent loan. These differences are smaller for less rapidly amortizing loans (GPMS) and larger on more rapid ones (the 15-year level payment). Note, finally, that the variation in the fair premia across loanto-value ratios is independent of the costs of default.

Analysis of how insurance fees ought to vary across mortgage instruments is facilitated by standardizing the data in Table 1 around the 30-year levelpayment mortgage (all one-time fees for a given loan-to-value ratio are divided by the fee for the 30-year level-payment mortgage). The variation in fair premia is enormous. Except for very high loan-to-value ratios and low default costs, the premia on graduated-payment mortgages are twice those on the 30-year level-payment mortgage. For 80 percent GPMs, fair premia are three to five times as large. The far greater proportional difference is due to the fact that the default option on the 80 percent 30 -year level payment mortgage is virtually "out of the money," while GPMs, especially that with rising payments for 10 years, is still in the money. The premia on the 15year mortgage, in contrast, is less than half that on the 30-year levelpayment mortgage and, for lower loan-to-value ratios and high default costs, is less than a quarter as large. 


\section{B. Alternative Inflation Senarios}

The premia in Table 4 indicate the sensitivity of the fair premia to the assumed expected inflation senario. Because the variance of inflation is known to be positively associated with its level, the variance parameter is changed along with the inflation rate. ${ }^{13}$ Premia are reported for $q=0.02$ $(\sigma=0.006)$ and $q=0.08(\because=0.014)$, as well as the base case of $q=0.05$ $(\sigma=0.01)$. With the standard 30-year mortgage, premia are marginally lower at higher inflation (and variance) rates and higher at lower inflation rates.

Tables 5 and 6 are similar to Tables 2 and 3 in that they illustrate the sensitivity of the premia for different parameters (inflation and its variance now, rather than default costs) across loan-to-value ratios and mortgage instruments by standardizing the premia on the 92 percent loan-to-value ratio and the standard 30 year mortgage, respectively. As can be seen in Table 5 , the premia across loan-to-value ratios are insensitive to the level of inflation. In contrast, the data in Table 6 indicate considerable mortgageinstrument sensitivity to inflation changes. More specifically, the faster the mortgage amortization, the more declines in expected inflation raise default premia and increases in expected inflation lower them. In fact, while the premium on the standard 30-year mortgage is negatively related to the level of expected inflation (see Table 4), the premium on the 15-year mortgage is positively related to inflation.

The data in Table 7 provide another example of the importance of the amortization path. Table 7 contains the fair premia for all the mortgages and all the loan-to-value ratios for both 9 and 13 percent mortgage rates. In each case, the risk-free rate is $1 \frac{1}{2}$ percentage points below the mortgage rate,

\footnotetext{
13 Parks (1978) documents a positive relationship between the variance of the inflation rates of the 12 major consumption expenditures categories in the U.S. NIPA and the square of the aggregate consumption inflation rate.
} 
the expected inflation and variance rates are 0.05 and 0.012 , and default costs are set at the high 0.3 value. Even though the inflation rate is identical, the insurance fees are uniformly lower for all instruments at the 9 percent rate because of the increased principal amortization. Fees on the 15-year mortgage are reduced the most, approximately 30 percent, followed by the fees on the GPMs which are reduced by about 20 percent. Fees on the standard 30-year mortgage are lowered by only about 5\%. These results correspond directly to the effect on principal amortization over time for each instrument. To illustrate, after five years the decreases in the outstanding principals on the three mortgages when the coupon rate is 9 percent, relative to when the rate is 13 percent, are 6 percent, 5 percent and 2 percent respectively.

C. An Extension to the Conventional Mortgage Market

In the conventional mortgage market, default risk is absorbed by lenders or shared by them and private mortgage insurers. All residential mortgages with initial loan-to-value ratios above 90 percent must carry private mortgage insurance, and, in practice, mortgages with loan-to-value ratios above 80 percent are so insured. This insurance typically covers the top $12 \%$ to $20 \%$ of mortgage claims; any residual risk is borne by the lenders. For initial loan-to-value ratios of 80 percent or less, lenders typically bear all default risk and pass the cost on to borrowers in the form of higher effective mortgage coupon rates.

The price (cost) of default risk that borrowers should be charged on $80 \%$ conventional loans is precisely the same fee that FHA should charge for a 80 \% loan-to-value ratio mortgage. Thus, computation of the fair default premium that should be built into 80 conventional mortgage rates is the same as 
computation of the fair FHA fee on such loans. ${ }^{14}$ These premia were reported in Tables 1 and 4 and are summarized as ranges in Table 8 for the different mortgage instruments. The "reasonable range" data in the far right column indicate that the default risk on $80 \%$ loan-to-value loans is negligible for the 15-year mortgage, is minor for the standard 30-year mortgage and is significant for the GPMs. That is, coupon rates on the standard mortgage should contain only a 10 basis point premium, while those on the GPMs should have a premium of a quarter to a half percentage point. ${ }^{15}$ of course, these calculations assume accurate house price appraisals, an assumption that might be tenuous in a period dominated by builder buy-downs and other creative financing techniques.

IV. Summary

An occupant of a house financed by mortgage debt will default on the debt if the gains from doing so exceed the perceived costs. There are two gains from default: the recapture of the negative equity in the house (the difference between the value of the mortgage and the value of the house) and the free rent that can be obtained between the time of default and actual foreclosure. The costs of default, covered by the term "moving costs," include dollar and psychic costs of moving, as well as losses of attachable assets and credit rating, to the extent they are relevant. Of course, if the household has to move lowing to an inability to make the mortgage payments or

14 Further, the difference between the fair fee on $95.8 \%$ FHA loans and the fee on $80 \%$ loans is a close approximation to the fee private mortgage insurers should change for $16 \%$ coverage on $95 \%$ loan-to-value loans. That is, the sum of the fee for coverage from $95 \%$ to $80 \%$ ( 16 percent of 95) and the residual fee on the remaining $80 \%$ is the same (approximately) as the fee on a 95.88 loan.

${ }^{15}$ Note from Table 7 that the premium on GPMs would be lowered by a quarter to a third if the market mortgage rate were to decline from 13 to 9 percent. 
a shift to a job in another location), then the costs of default are greatly reduced because many of the moving costs must be paid whether or not default occurs. Our analysis of moving costs suggest that they are proportional to the value of the house at the time default is being considered and that the factor of proportionality ranges between 0.15 and 0.3 for most households.

Expected default losses on any mortgage contract depend on the likelihood of default and the expected losses associated with its occurrence. Both are functions of the known mortgage path, the probabilities of alternative house price paths, and household moving costs. Mortgage insurance premia should cover the expected default losses. Following the logic of Black and Scholes, we derived a partial differential equation governing this premia. The critical issue to evaluation of the equation is determining when default occurs. If the insurance were a pure put option, then default would occur when the value of the insurance equaled the negative equity in the house. However, we have shown that the borrower's default decision is driven by his moving costs. As a result, default will not occur until significant negative equity occurs.

Insurance premia were:calculated for four mortgages -- 30 and 15 year level payment (LPMS) and 30 year graduated payment (GPMS) with 5 and 10 year graduation at 7.5 and 4.9 percent per annum, respectively -- and for four loan-to-value (LV) ratios -- 95.8 (very high), 92 (high), 88 (moderate) and 80 (low) percent. While FHA charges the same premium for all mortgages and LVs, our calculated fair premia vary widely, suggesting substantial crosssubsidies in the FHA program. In a 5 percent expected inflation environment, very high LV 30 year LPMs are 65 percent riskier than high LV loans. Moderate and low LV loans are 40 and 80 percent less risky, respectively. To illustrate, the 95.8 percent loan is nearly four times as risky as the 88 
percent loan and thus should have four times as large an insurance premium. (These differences are up to twice as great for the 15 year mortgage and somewhat smaller for GPMs.) All differences are quite insensitive to the assumed level of default costs and to changes in the inflation (and variance) rates. The cross-subsidies among 30-year LPM borrowers are substantial because there is, in fact, wide variance in loan-to-value ratios of FHA borrowers. In the 1980-82 period, for example, 40 percent of borrowers had loan-to-value ratios below 90 percent (nearly 20 percent had ratios of 80 percent or less), while 30 percent had ratios of 95 percent or higher. Our estimates suggest that half of the premia of the former are, on average, used to subsidize the latter.

Looking across mortgage instruments, at moderate and very high LVs, GPMs are generally 2 to 3 times as risky as the 30 year LPM. Moderate and high LV 10 year GPMs are even riskier for households with high default costs, and low LV 10 year GPMs are 4 to 6 times as risky. On the other hand, the 15 year LPM is 50 to 80 percent less risky than the 30 year LPM, with the differences in riskiness being greater for lower LV loans and for households with high default costs. Thus expanding the mortgage menu further increases the possible magnitude of cross-subsidies. This expansion, particularly when it includes riskier PLAM and ARM loans, could also lead to substantial net FHA losses.

The default risk on 80 percent LV loans is roughly the residual risk of lenders in conventional loan markets (the greater risk on higher LV losses is borne by private mortgage insurers). These expected default losses must be recovered via higher mortgage coupon rates. Our analysis suggests that an extra 5 to 15 basis point charge is sufficient on the standard 30 year LPM. 
For the 15 year LPM, the charge is less than 5 basis points, but for the GPMs, the appropriate charge is 15 to 60 basis points, with the 10 year GPM requiring the largest fee. 
Appendix :

Taxes, Service Flows and the Equilibrium Insurance Premium

In a world of taxes, the formation of the hedge position in houses and insurance contracts will generate an aggregate after-tax return. If we decompose this return, we see that each component will be taxed at a different rate and will depend on who forms the hedge. Gains and losses from the house appreciation would be taxed at the capital gains rate of $\tau$ ' changes in the value of the insurance contracts would be taxed at the ordinary rate of $\tau$, and the after-tax service flow from the house, which now includes the depreciation tax shield, will reflect the tax rate on ordinary income of the marginal landlord. In equilibrium, the after-tax rate of service flow (s') can be expressed as

$$
S^{\prime}=(1-\tau) r-(1-\tau) q .
$$

In a no tax world, $s^{\prime}=s=r-q$.

With the introduction of taxes, the government becomes a partner in the equity position. It shares $\tau_{q}$ of the risk of house price appreciation and $\tau$ of the risk of the insurance contract. Therefore, the perfect hedge position requires the purchase of $\left(1-\tau_{q}\right) / I_{H}(1-\tau)$ insurance contracts for each house purchased. The equity position would then earn the after-tax riskless rate. As a result, the tax analogue to (1), after canceling the mortgage terms, is: 
$d H\left(1-\tau_{q}\right)+s^{\prime} H d t-d I(1-\tau)\left(1-\tau_{q}\right) / I_{H}(1-\tau)=\left[H-I\left(1-\tau_{q}\right) / I_{H}(1-\tau)\right] r(1-\tau) d t$.

Substituting (3) into (b) and simplifying results in:

$$
I_{t}=r I-\left[\frac{r(1-\tau)}{\left(1-\tau q^{\prime}\right.}-\frac{s^{\prime}}{\left(1-\tau q^{\prime}\right.}\right] H I_{H}-\frac{1}{2} \sigma^{2} H^{2} I_{H H} .
$$

If we now substitute the expression for the equilibrium service flow (a) into (b'), we discover that all the tax variables are eliminated and the partial differential equation governing the equilibrium insurance premium is simply:

$$
I_{t}=r I-q H I_{H}-\frac{1}{2} \sigma^{2} H^{2} I_{H H} .
$$

This is the same expression as the no-tax model (1'). As long as the marginal real estate investor forms the hedge position, the specific tax rate of this investor is irrelevant owing to the adjustment of the equilibrium service flow and the hedge ratio to this investor's tax bracket. 


\section{References}

Asay, M. R., Rational Mortgage Pricing, unpublished manuscript, December 1978. Black, F. and M. Scholes, "The Pricing of options and Corporate Liabilities," Journal of Political Economy, May/June 1973.

Brennan, M. J. and E. S. Schwartz, "The Valuation of American Put options," The Journal of Finance, May 1977.

Buser, S. A. and Hendershott, P. H., "The Pricing of Default-Free Mortgages," paper presented to the Midyear Meetings of the AREUEA, May 1984.

Campbell, T. S. and J. K. Dietrich, "The Determinants of Default on Insured Conventional Residential Mortgage Loans," The Journal of Finance, December 1983.

Foster, C. and R. Van Order, "An Option-Based Model of Mortgage Default," mimeo, U.S. Department of Housing and Urban Development, March 1984. Parks, R. W., "Inflation and Relative Price Variablility," Journal of Political Economy, February 1978.

Pesando, J. E. and S. M. Turnbull, "Default Risk of Alternative Mortgage Instruments: A Simulation study," mimeo, January 1983.

Swan, C., "Pricing Private Mortgage Insurance," Journal of American Real Estate and Urban Economics Association, Fall 1982.

von Furstenburg, G., "Risk Structures and the Distribution of Benefits within the FHA Home Mortgage Insurance Program," Journal of Money Credit and Banking, August 1970 . 


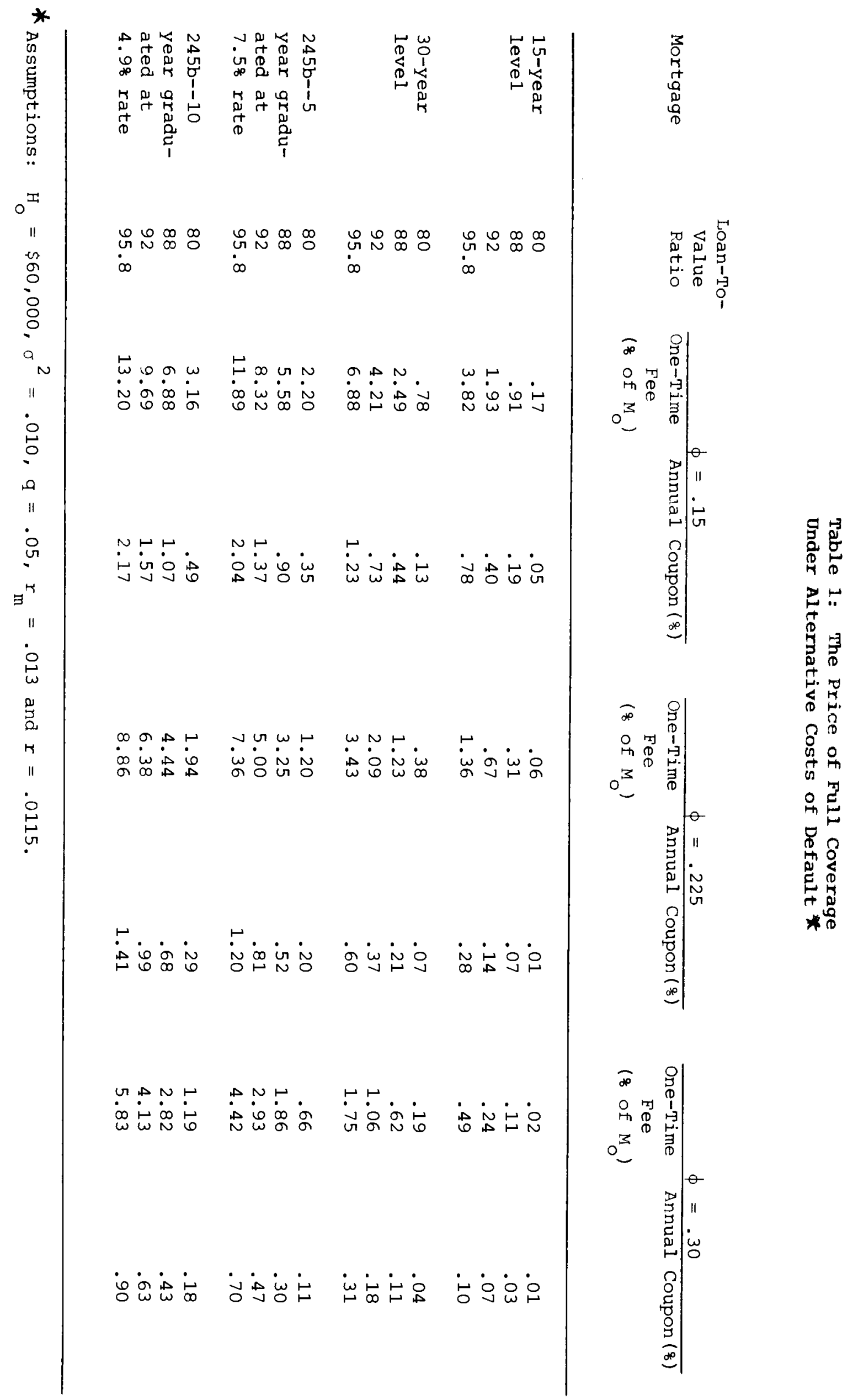



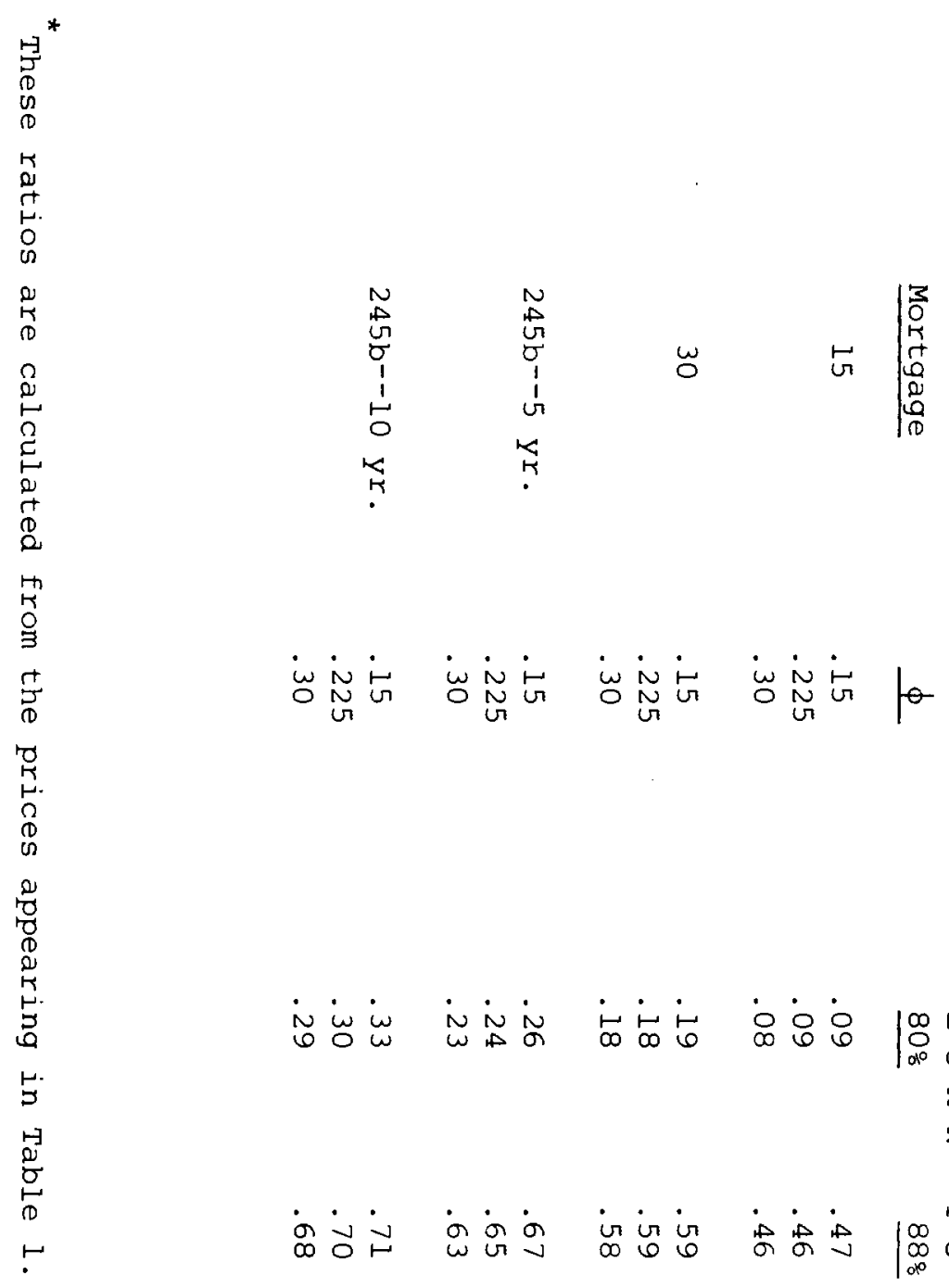

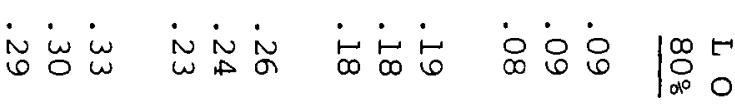

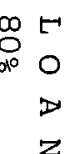

क人்

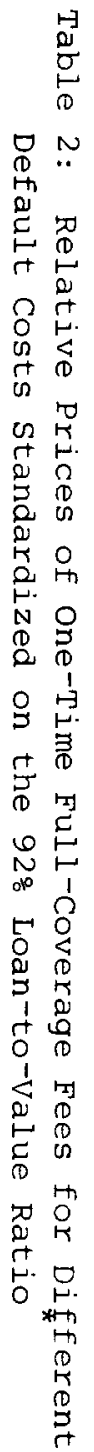



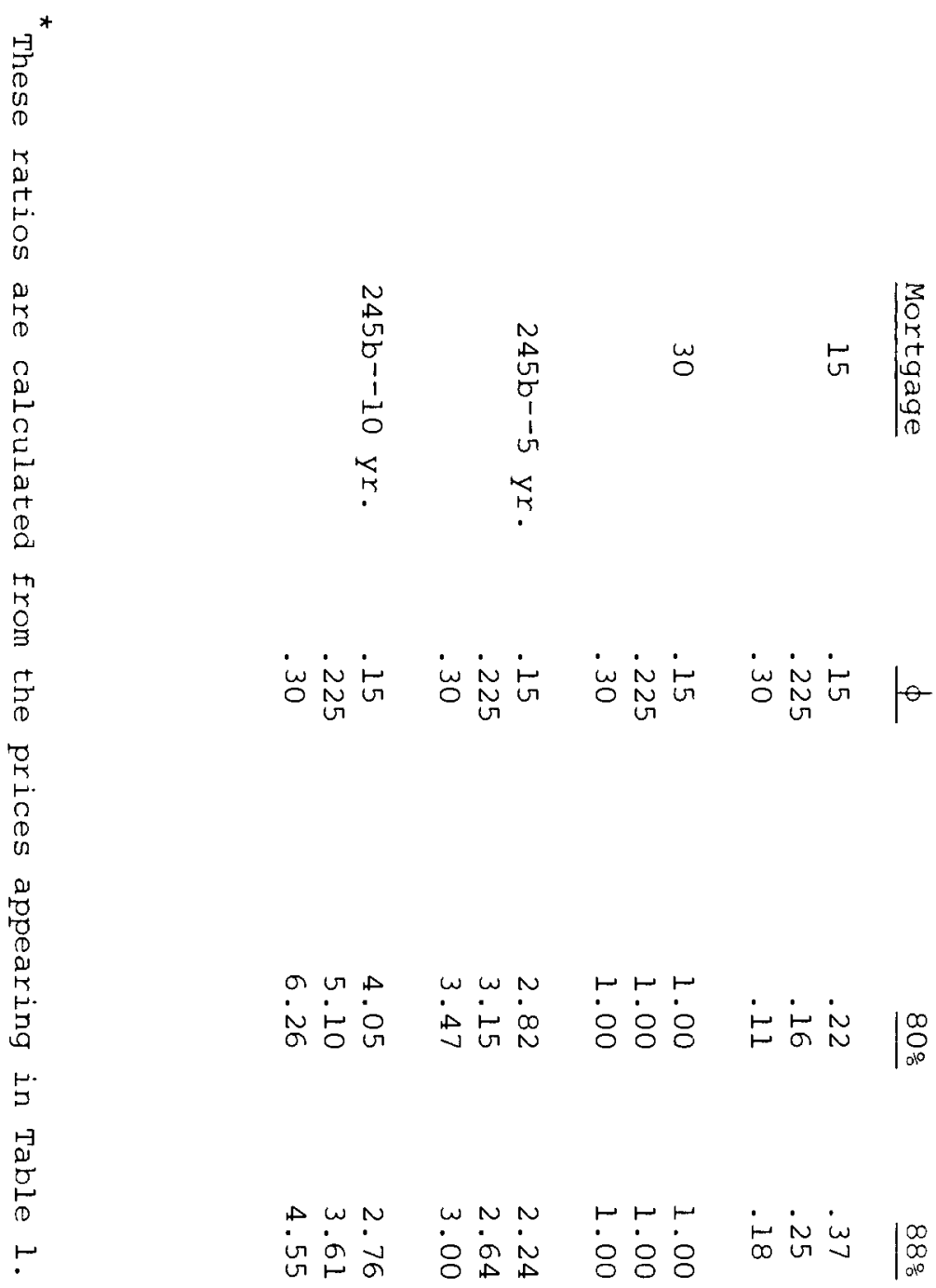

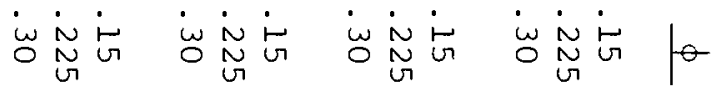

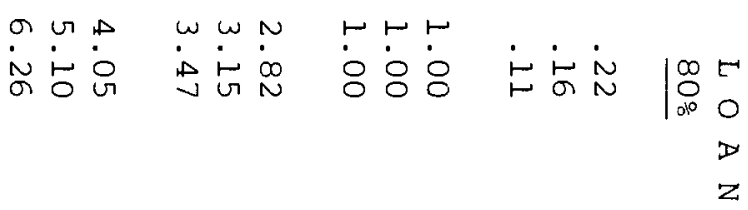

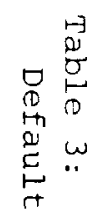

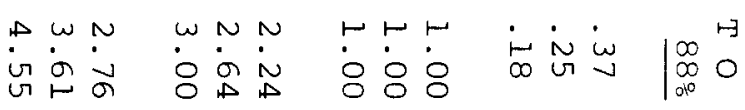

w. ஓंष

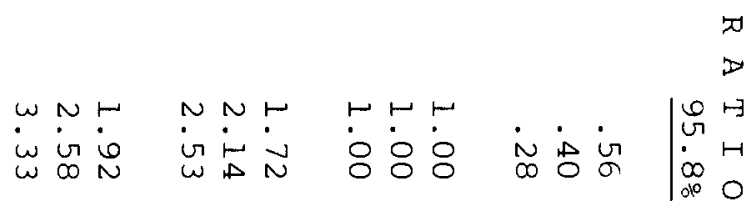




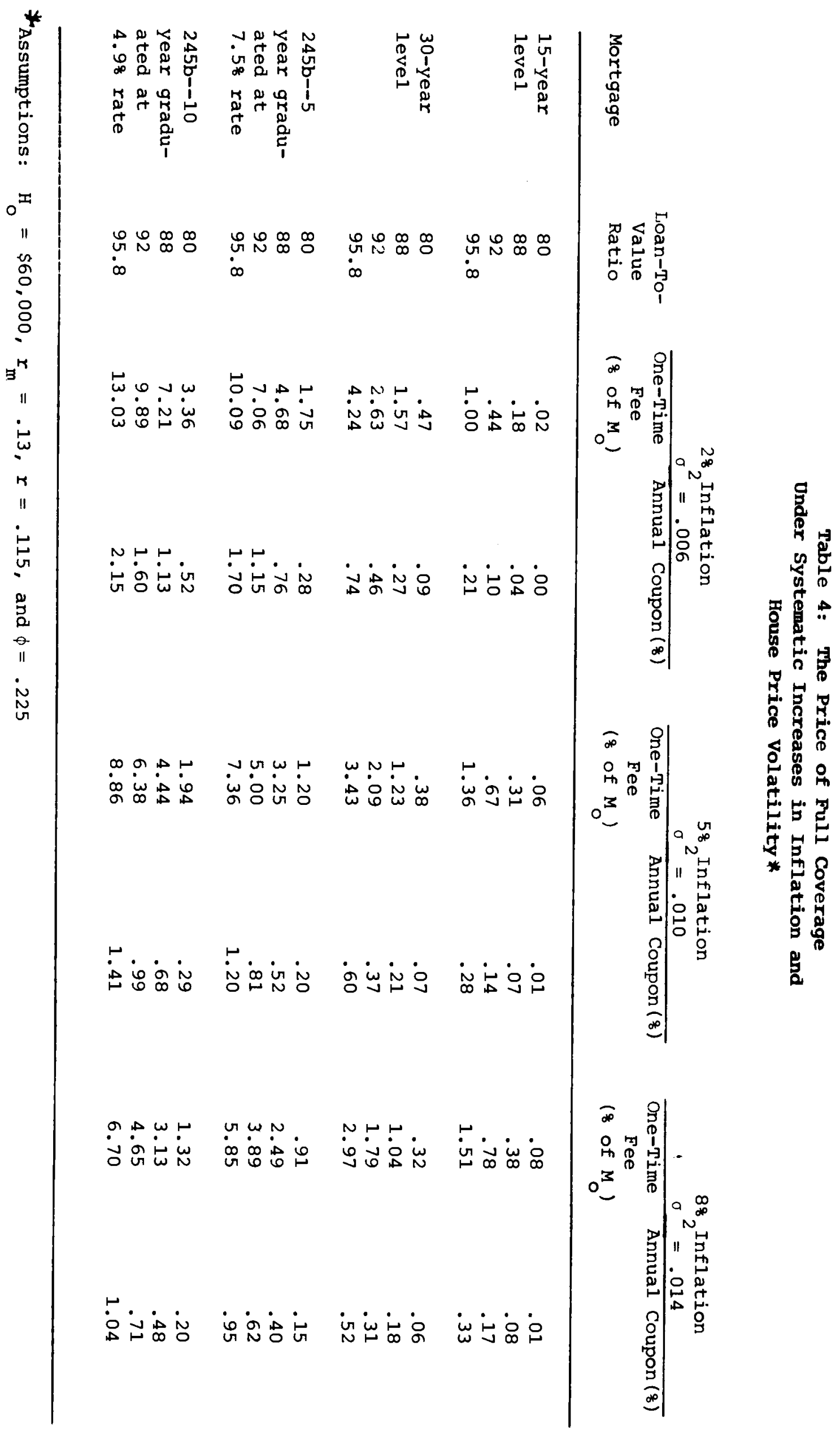




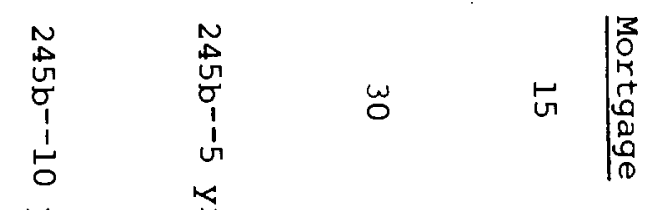

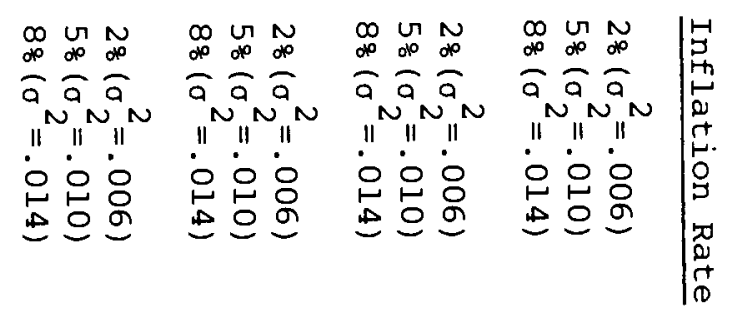

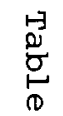

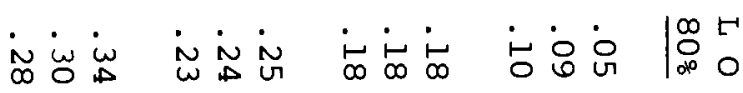

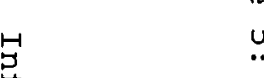

ज

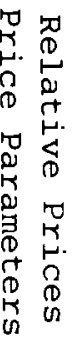

in

苟

范

垔.

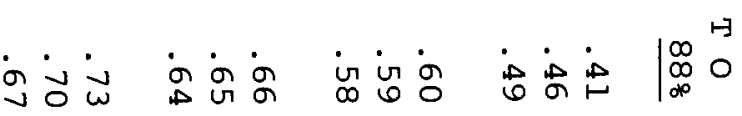

\&

号 苞

苗

மே. ㅇㅇㅇㅇㅇㅇㅇㅇㅇㅇㅇ

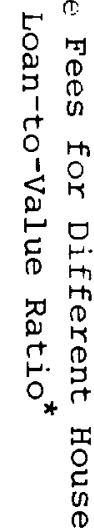

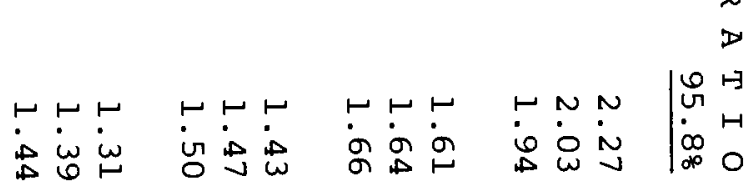




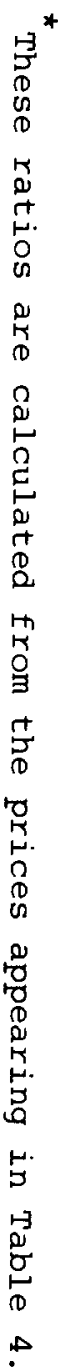

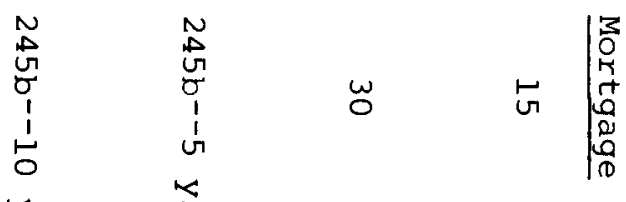

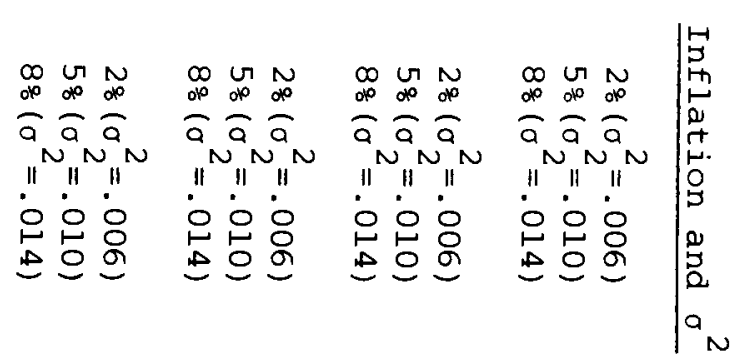

范满

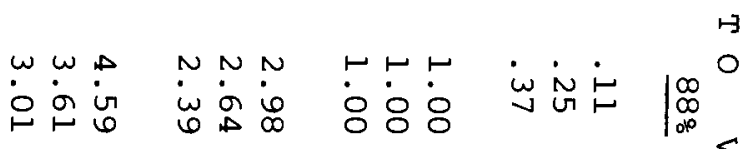

New $N$ N N N

i்

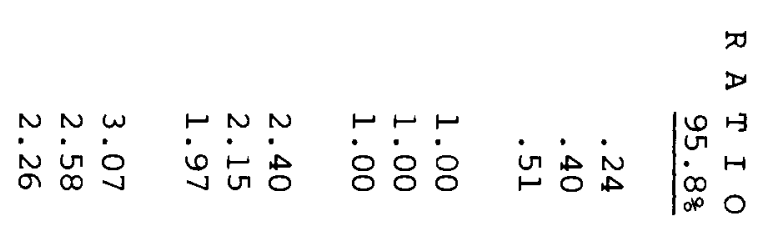

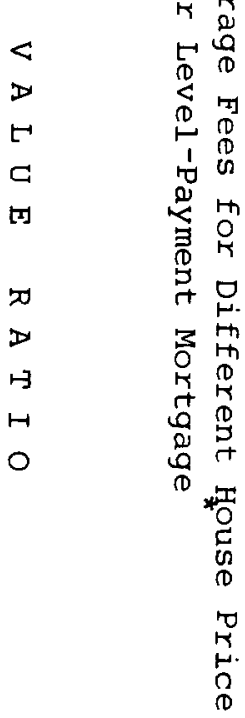




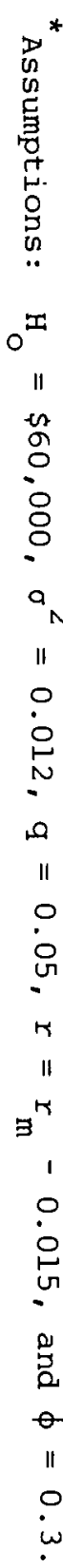

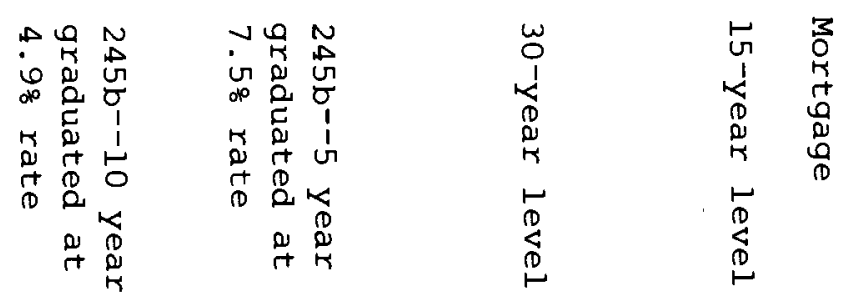

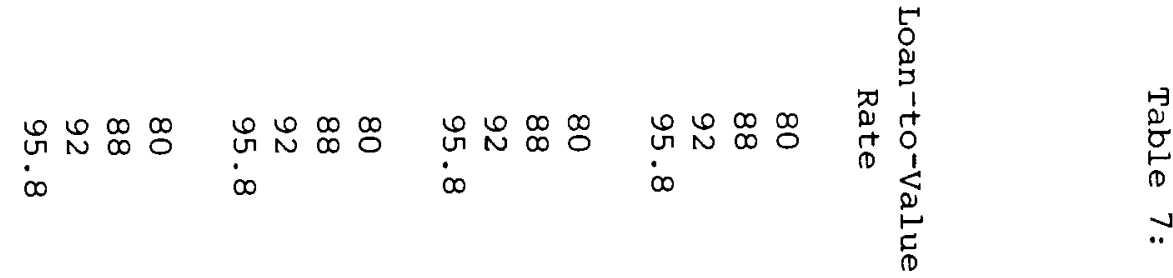

20

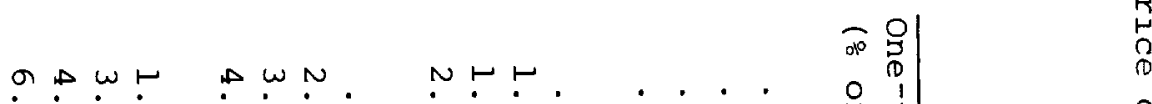

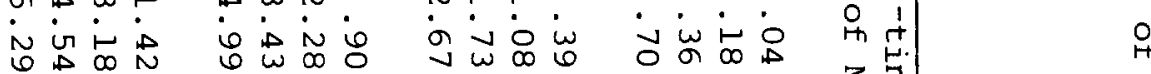

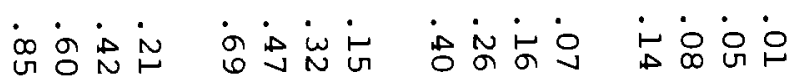

$\stackrel{\text { TI }}{\Xi}$

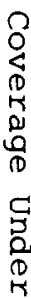

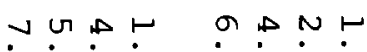

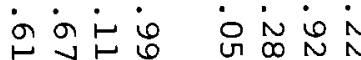

$N \vdash \vdash$

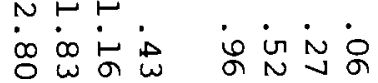

do

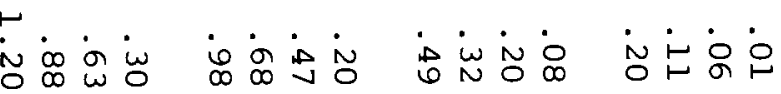




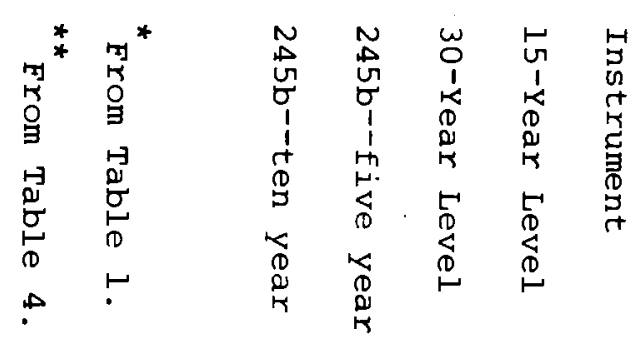
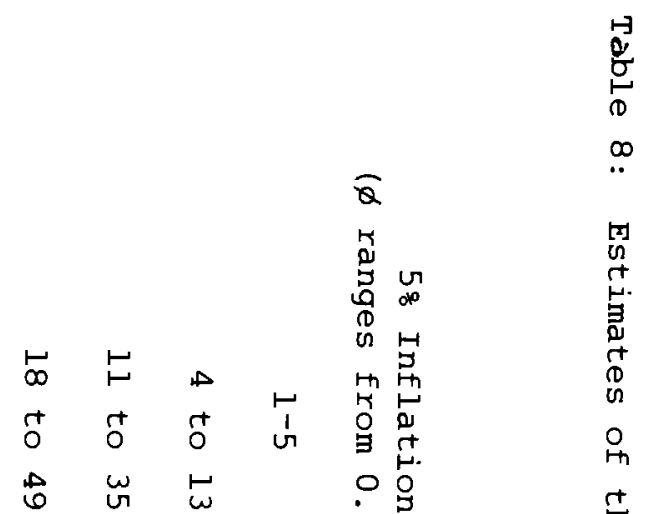

$\widehat{Q}$

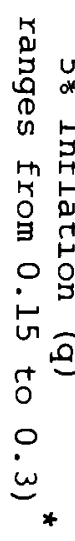

a

1
$\mathfrak{g}$
$\mathfrak{5}$
0
0
0

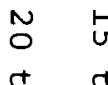

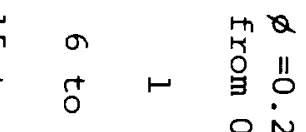

N $N 0$ :

ก

.

$\stackrel{\circ}{\infty}$

$*$

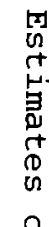

年

每

O

滎

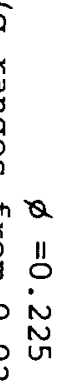

जी प

용.

i

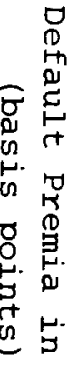

节

尔

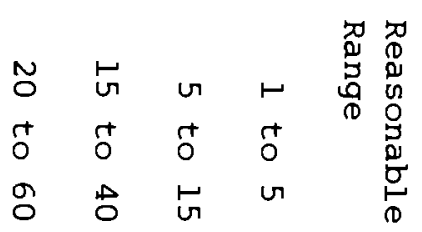

